\title{
JIMMBA
}

\section{Analisis Pengaruh Profitabilitas, Likuiditas, Operating Capacity, Sales Growth Terhadap Kondisi Financial Distress pada Perusahaan Manufaktur yang Terdaftar di Bursa Efek Indonesia Tahun 2015-2018}

\author{
Arif Wibowo ${ }^{1}$, Aris Susetyo ${ }^{2}$ \\ 1,2Sekolah Tinggi Ilmu Ekonomi Putra Bangsa \\ Email: arief.1093@gmail.com ${ }^{1}$, arisputrabangsa75@gmail.com²
}

\section{ARTICLE INFO}

Article History:

Received: October 24th 2020

Accepted: November $1^{\text {st }} 2020$

Published: December $1^{\text {st }} 2020$

Keywords:

Profitability, Liquidity, Operating Capacity, Sales Growth,Financial Distress

\begin{abstract}
Penelitian ini bertujuan untuk menguji pengaruh profitabilitas, likuiditas, operating capacity dan sales growth terhadap financial distress. Penelitian ini difokuskan pada perusahaan manufaktur yang terdaftar di Bursa Efek Indonesia (BEI) periode 2015-2018. Jumlah pengamatan sebanyak 172 sampel penelitian yang diperoleh dengan metode nonprobability sampling yaitu teknik purposive sampling. Teknik analisis yang digunakan dalam penelitian ini adalah analisis regresi logistik. Berdasarkan hasil analisis menunjukkan bahwa: (1) Profitabilitas berpengaruh negatif dan signifikan terhadap financial distress. Hal ini berarti bahwa semakin tinggi profitabilitas maka dapat menekan terjadinya kondisi financial distress. (2) Likuiditas berpengaruh negatif dan signifikan terhadap financial distress. Hal ini menunjukkan bahwa semakin besar adanya ketersediaan atau kecukupan dana untuk memenuhi kewajibannya, maka semakin kecil kemungkinan perusahaan mengalami kondisi financial distress yang mengakibatkan pada kebangkrutan. (3) Operating Capacity berpengaruh negatif dan signifikan terhadap financial distress. Hal ini menunjukan bahwa semakin rendah penjualan perusahaan yang diakibatkan dengan penggunaan aset yang tidak efektif untuk kegiatan operasional, maka perusahaan akan rentan terhadap kondisi financial distress. (4) Sales growth tidak berpengaruh terhadap kondisi financial distress. Koefisien determinasi Nagelkerke R Square sebesar 0,734 yang berarti kemampuan variabel penelitian yang diproksikan dengan return on asset, current ratio, total asset turnover ratio dan sales growth menjelaskan variabel prediksi financial distress sebesar $73.4 \%$. Sisanya sebesar $26.6 \%$ merupakan faktor lain di luar model penelitian.
\end{abstract}




\section{Pendahuluan}

Kondisi ekonomi yang melemah mengakibatkan goncangan dasyat pada sektor keuangan perusahaan baik itu perusahaan besar, kecil, nasional maupun multinasional. Indrawati (2019) mengatakan bahwa risiko pelemahan ekonomi dunia saat ini semakin meningkat. Efek dari pelemahan ekonomi dunia salah satunya adalah pada keuangan perusahaan. Keuangan perusahaan yang tidak stabil yang berakibat pada kinerja keuangan semakin tidak terkendali. Ketidakmampuan perusahaan dalam mengendalikan keuangan yang tidak stabil akan mengakibatkan kinerja keuangan yang semakin menurun. Sering kali perusahaan yang telah beroperasi dalam jangka waktu yang cukup lama mengalami ketidakstabilan dalam hal keuangan. Terdapat beberapa perusahaan atau emiten yang mengalami kondisi keuangan tidak stabil yang tercatat dalam Bursa Efek Indonesia (BEI).

Ketidakstabilan keuangan perusahaan akan berakibat pada kebangkrutan atau likuidasi. Kebangkrutan sering disebut likuidasi atau penutupan perusahaan atau insolvensi (Dwijayanti, 2010). Sedangkan menurut Prihadi (2008: 177), Kebangkrutan merupakan kondisi dimana perusahaan tidak mampu lagi untuk melunasi kewajibannya. Kebangkrutan adalah kondisi dimana sebuah perusahaan mengalami kesulitan keuangan dan tidak mampu mengoprasikan perusahaan dengan baik. Terjadinya likuidasi atau kebangkrutan pada sejumlah perusahaan terdaftar tentu saja akan menimbulkan beberapa permasalahan yang berkaitan dengan pemilik, investor maupun karyawan yang bekerja pada perusahaan tersebut. Kebangkrutan (Bankruptcy) adalah kondisi disaat perusahaan mengalami ketidakcukupan dana untuk menjalankan usahanya. Kebangkrutan ditandai dengan adanya financial distress yaitu keadaan dimana perusahaan lemah dalam menghasilkan laba atau cenderung mengalami defisit (Dwijayanti, 2010).

Hofer (1980) berpendapat bahwa financial distress merupakan kondisi dimana perusahaan mengalami laba bersih negatif selama beberapa tahun. Pendapat tersebut diperkuat oleh Whitaker (1999) yang menyatakan bahwa financial distress adalah kondisi dimana arus kas yang ada lebih kecil daripada porsi utang jangka panjang yang akan jatuh tempo, adanya pemberhentian tenaga kerja, atau jika selama 2 tahun mengalami laba bersih operasi negatif dan selama lebih dari satu tahun tidak melakukan pembayaran dividen. Sedangkan menurut Ghozali (2012:143) financial distress merupakan suatu kondisi dimana keuangan perusahaan dalam keadaan tidak sehat, atau krisis yang terjadi sebelum kebangkrutan. Financial distress dimulai dari ketidakmampuan dalam memenuhi kewajiban-kewajibannya, terutama kewajiban yang bersifat jangka pendek termasuk kewajiban likuiditas, dan juga termasuk kewajiban dalam kategori solvabilitas. Permasalahan terjadinya insolvency (keadaan tidak mampu membayar) dapat terjadi karena faktor berawal dari kesulitan likuiditas.

Proses financial distress ditandai oleh beberapa faktor penyebab sebelum perusahaan benarbenar mengalami kebangkrutan, sehingga tidak dapat menjalankan operasi perusahaan. Beberapa faktor yang dapat mengindikasikan kondisi dimana perusahaan mengalami financial distress yaitu merger, akusisi dan delisting pada perusahaan yang telah malakukan pencatatan saham (listing) di Bursa Efek Indonesia (BEI). Faktor-faktor tersebut telah terjadi pada beberapa perusahaan manufaktur yang melakukan pencatatan saham di Bursa Efek Indonesia (BEI).

Perusahaan manufaktur adalah suatu cabang industri yang mengaplikasikan mesin, peralatan, dan tenaga kerja untuk mengubah bahan mentah menjadi barang jadi untuk dijual. 
Perusahaan manufaktur sebagai salah satu jenis dari entitas yang menjadikan pencapaian profit sebagai tujuan utamanya memiliki rangkaian aktivitas bisnis yang relatif lebih kompleks dibandingkan dengan jenis perusahaan lainnya. Dalam prosesnya, kegiatan produksi memerlukan perhitungan yang tepat agar kegiatan operasional produksi dapat terus berlangsung. Perhitungan tersebut meliputi ketepatan akan perhitungan kebutuhan bahan baku, ketepatan estimasi waktu pemesanan bahan baku dimana hal ini penting untuk menjamin bahwa bahan baku yang digunakan adalah bahan baku dengan kualitas terbaik dan tidak kadaluarsa, ketepatan perhitungan kebutuhan tenaga kerja serta berbagai beban operasional lainnya.

Perusahaan manufaktur melakukan merger dan akuisisi, guna mengembalikan kesetabilan kondisi keuangan untuk menghindari financial distress. Beberapa contoh perusahaan manufaktur yang melakukan merger dan akuisisi adalah PT. Multistratda Arah Sarana Tbk (MASA) dengan Michelin dengan nilai US\$ 439 (Rp 6,2 triliun), PT Kimia Farma Tbk yang melakukan akuisisi dengan jaringan ritel farmasi asal arab Saudi Dwaa Ltd. Co. Senilai Rp 130 miliar dan PT Semen Indonesia Tbk (SMGR) yang melakukan akuisisi dengan PT Holcim Indonesia Tbk (SMCB) senilai US\$ 917 juta (kontan.co.id). Tindakan merger dan akuisisi mengindikasikan perusahaan mengalami kondisi financial distress. Sebagai akibat dari rangkaian aktivitas bisnis yang relatif lebih panjang, maka perusahaan manufaktur menghadapi tantangan yang lebih kompleks dalam upayanya mempertahankan keberlangsungan hidupnya. Oleh karena itu analisis kebangkrutan atas perusahaan manufaktur menjadi hal yang penting untuk dilakukan. Selain itu juga untuk menilai kinerja keuangan sebagai syarat pencatatan saham pada Bursa Efek Indonesia.

Proses pencatatan perusahaan atau emiten dalam Bursa Efek Indonesia (BEI) atau yang dikenal dengan istilah listing mempunyai beberapa persyaratan diantaranya yaitu mengenai masalah finansial. Masalah finansial perusahaan yang akan dicatatkan dalam lantai bursa efek didasarkan pada laporan keuangan Auditan terakhir sebelum mengajukan permohonan pencatatan. Berdasarkan laporan auditan terakhir terdapat dua kriteria perusahaan yang akan dicatat pertama kalinya yaitu dalam papan utama atau papan pengembangan. Pada papan utama dan papan pengembangan perusahaan harus mempunyai laporan keuangan auditan terakhir dengan nilai aktiva berwujud bersih (Net Tangible Asset) sesuai dengan peraturan yang telah ditetapkan oleh bursa efek.

Hoesen (2014) mengatakan bahwa perusahaaan atau emiten yang tercantum dalam papan utama bursa adalah perusahaan yang sudah beroperasi selama tiga tahun. Selama proses listing, perusahaan harus mengikuti aturan yang ditetapkan oleh Bursa Efek Indonesia (BEI), apabila tidak mengindahkan aturan, maka perusahaan akan di delisting (penghapusan pencatatan). Delisting merupakan penghapusan pencatatan saham pada Bursa Efek Indonesia (BEI). Setelah terjadinya delisting, saham sudah tidak dapat ditransaksikan dalam lantai bursa. Status perusahaan yang mengalami delisting biasanya tetap menjadi perusahaan publik namun sahamnya sudah tidak tercatat dalam lantai bursa. Terdapat dua jenis delisting perusahaan yaitu Voluntary Delisting (Delisting Sukarela) dan Forced Delisting (Delisting Paksa) (Wira, 2018).

Voluntary Delisting (Delisting Sukarela) yaitu perusahaan sendiri yang mengajukan delisting karena alasan tertentu. Misalnya karena kehendak pengendali baru, akibat merger, atau alasan lainnya. Delisting sukarela biasanya dipandang positif. Pemegang saham tidak perlu khawatir, karena ada kewajiban untuk menyerap saham di publik pada harga yang wajar. 
Biasanya harganya cenderung lebih tinggi daripada harga pasar. Sedangkan Forced Delisting (Delisting Paksa) merupakan delisting yang dilakukan oleh otoritas bursa (BEI) berdasar aturan yang berlaku. Misalnya karena saham sudah disuspensi dua tahun berturut-turut karena tidak menyampaikan laporan keuangan, keberlangsungan bisnis perusahaan dipertanyakan dan tidak ada penjelasan, dan alasan lainnya. Investor saham yang memiliki saham yang delisting paksa biasanya dirugikan (Wira, 2018).

Berikut ini merupakan daftar perusahaan yang mengalami delisting pada Bursa Efek Indonesia (BEI) mulai dari tahun 2015 hingga tahun 2019:

Tabel 1. Daftar Delisting Perusahaan dalam BEI Tahun 2015-2019

\begin{tabular}{cclcc}
\hline No & $\begin{array}{c}\text { Kode } \\
\text { Perusahaan }\end{array}$ & \multicolumn{1}{c}{ Nama Perusahaan } & $\begin{array}{c}\text { Tanggal } \\
\text { Pencatan }\end{array}$ & Delisting Date \\
\hline 1 & NAGA & PT Bank Mitraniaga Tbk. & 09 Jul 2013 & 23 Ags 2019 \\
2 & SIAP & Sekawan Intipratama Tbk. & 17 Okt 2008 & 17 Jun 2019 \\
3 & ATPK & Bara Jaya Internasional Tbk. & 17 Apr 2002 & 30 Sep 2019 \\
4 & BBNP & Bank Nusantara Parahyangan Tbk. & 10 Jan 2001 & 02 Mei 2019 \\
5 & GMCW & Grahamas Citrawisata Tbk. & 14 Feb 1995 & 13 Ags 2019 \\
6 & DAJK & PT Dwi Aneka Jaya Kemasindo Tbk. & 14 Mei 2014 & 18 Mei 2018 \\
7 & TRUB & Truba Alam Manunggal Engineering Tbk. & 16 Okt 2006 & 12 Sep 2018 \\
8 & JPRS & Jaya Pari Steel Tbk. & 04 Ags 1989 & 08 Okt 2018 \\
9 & SQBB & Taisho Pharmaceutical Indonesia Tbk. & 29 Mar 1983 & 21 Mar 2018 \\
10 & CPGT & PT Citra Maharlika Nusantara Corpora Tbk. & 09 Jul 2013 & 19 Okt 2017 \\
11 & BRAU & Berau Coal Energy Tbk. & 19 Ags 2010 & 16 Nov 2017 \\
12 & INVS & Inovisi Infracom Tbk. & 03 Jul 2009 & 23 Okt 2017 \\
13 & CTRP & Ciputra Property Tbk. & 07 Nov 2007 & 19 Jan 2017 \\
14 & LAMI & Lamicitra Nusantara Tbk & 18 Jul 2001 & 28 Des 2017 \\
15 & CTRS & Ciputra Surya Tbk & 15 Jan 1999 & 19 Jan 2017 \\
16 & SOBI & Sorini Agro Asia Corporindo Tbk. & 03 Ags 1992 & 03 Jul 2017 \\
17 & TKGA & PT Permata Prima Sakti Tbk. & 06 Jan 1992 & 16 Nov 2017 \\
18 & DAVO & Davomas Abadi Tbk. & 22 Des 1994 & 21 Jan 2015 \\
19 & BAEK & PT. Bank Ekonomi Raharja Tbk. & 8 Jan 2008 & 10 Sep 2015 \\
20 & UNTX & PT. Unitex Tbk. & 12 Mei 1982 & 10 Sep 2015 \\
\hline
\end{tabular}

Sumber: www.idx.id

Berdasarkan data Bursa Efek Indonesia pada tahun 2015 sampai dengan tahun 2019 terdapat 7 perusahaan manufaktur yang mengalami penghapusan pencatatan (delisting) dari Bursa Efek Indonesia (BEI). Perusahaan manufaktur yang mengalami delisting yaitu PT. Sekawan Intipratama Tbk (SIAP), PT Dwi Aneka Jaya Kemasindo Tbk (DAJK), Jaya Pari Steel Tbk (JPRS), Taisho Pharmaceutical Indonesia Tbk (SQBB), Sorini Agro Asia Corporindo Tbk (SOBI), Davomas Abadi Tbk (DAVO) dan PT. Unitex Tbk (UNTX). Terjadinya proses delisting dapat mengindikasikan kondisi keuangan perusahaan yang menurun mendekati kondisi kebangkutan atau sering disebut dengan Financial Distress. Menurut Luciana (2004) menyatakan bahwa financial distress sebagai suatu kondisi dimana perusahaan mengalami delisted akibat laba bersih dan nilai buku ekuitas negatif berturut-turut serta perusahaan tersebut telah dimerger. Berbeda dengan Hanifah (2013), yang menyatakan bahwa kesulitan keuangan atau disebut juga financial distress diartikan sebagai tahap penurunan kondisi keuangan yang terjadi sebelum kebangkrutan. 
Financial distress dapat diukur melalui laporan keuangan dengan cara menganalisis laporan keuangan (Imam dan Reva, 2012). Salah satu cara dalam menganalisis laporan keuangan dengan melakukan perhitungan rasio keuangan. Analisis laporan keuangan perlu dilakukan agar informasi laporan keuangan mudah dipahami sebagai pengambilan keputusan (Kanya et al., 2014). Laporan keuangan merupakan hasil dari suatu aktivitas yang bersifat teknis berdasar pada metode dan prosedur-prosedur yang memerlukan penjelasan-penjelasan agar tujuan atau maksud untuk menyediakan informasi yang bermanfaat dapat dicapai. Laporan keuangan yang dapat dijadikan dasar untuk mengukur kondisi financial distress suatu perusahaan melalui analisis yaitu dengan menggunakan rasio profitabilitas, rasio likuiditas, operating capacity dan sales growth.

Rasio profitabilitas merupakan rasio untuk menilai kemampuan perusahaan dalam mencari keuntungan atau laba dalam suatu periode tertentu (Kasmir, 2015). Rasio ini juga memberikan ukuran tingkat efektifitas manajemen suatu perusahaan yang ditunjukan dari laba yang dihasilkan dari penjualan atau dari pendapatan investasi. Laba yang dihasilkan perusahaan salah satunya berasal dari penjualan yang dilakukan perusahaan. Salah satu ukuran kinerja perusahaan yang sering digunakan sebagai dasar pengambilan keputusan adalah laba yang dihasilkan oleh perusahaan (Rachmawati et al. 2007). Profitabilitas yang tinggi menunjukkan prospek perusahaan yang bagus sehingga investor akan merespon positif dan nilai perusahaan akan meningkat (Sujoko dan Soebintoro, 2007). Selain itu, profitabilitas juga merupakan hasil akhir bersih dari berbagai kebijakan dan keputusan, dimana rasio ini digunakan sebagai alat pengukur atas kemampuan perusahaan untuk memperoleh keuntungan dari setiap rupiah penjualan yang dihasilkan. Profitabilitas adalah tingkat keberhasilan atau kegagalan suatu perusahaan selama jangka waktu tertentu (Atmini, 2005). Rasio keuangan selanjutnya yang dapat mengukur financial distress yaitu rasio likuiditas.

Rasio likuiditas merupakan rasio yang mengukur kemampuan perusahaan untuk membayar kewajibannya. Rasio likuiditas menunjukkan sejauh mana aktiva lancar menutupi kewajibankewajiban lancar (Sofyan, 2015:301). Hal tersebut senada dengan penyataaan Subramanyam (2010:45), yang menyatakan bahwa likuiditas merujuk pada kemampuan perusahaan untuk memenuhi kewajiban jangka pendeknya. Rasio likuiditas dapat digunakan untuk memprediksi terjadinya financial distress. Rasio likuiditas yang penting adalah rasio lancarketersediaan aset lancar untuk memenuhi kewajiban lancar. Rasio likuiditas yang dipakai dalam berbagai penelitian adalah rasio lancar (current ratio).

Selain rasio profitabilitas dan rasio likuiditas, operating capacity dan sales growth juga dapat digunakan sebagai indikator dalam memprediksi terjadinya financial distress. Menurut Atika (2012), operating capacity merupakan rasio yang digunakan untuk menilai efektif atau tidaknya perusahaan dalam menggunakan aset-aset guna menghasilkan penjualan. Rasio ini dinilai dari total asset turnover ratio (TATO), dimana total penjualan dibagi dengan total aset yang dimiliki perusahaan. Semakin efektif suatu perusahaan dalam menggunakan asetnya untuk menghasilkan penjualan maka diharapkan keuntungan yang didapatkan akan semakin besar. Namun sebaliknya jika penggunaan aset perusahaan tidak efektif maka akan berakibat perusahaan mengalami potensi financial distress.

Selanjutnya pertumbuhan penjualan (Sales growth) juga dapat digunakan untuk mengukur pertumbuhan perusahaan. Perusahaan yang pertumbuhan penjualannya positif dan semakin tinggi lebih cenderung dapat mempertahankan kelangsungan usahanya serta menurunkan potensi terjadinya kondisi financial distress dibandingkan perusahaan dengan pertumbuhan 
penjualan yang negatif dan semakin rendah. Pattinasarany (2010) menjelaskan bahwa rasio sales growth digunakan untuk mengukur tingkat pertumbuhan penjualan pada suatu periode. Rasio sales growth dihitung dengan cara mengurangi sales periode sekarang dengan periode sebelumnya, kemudian dibagi dengan sales periode sebelumnya.

\section{Kajian Teori dan Telaah Literatur}

\section{Financial Distress}

Kondisi financial distress adalah kondisi dimana keuangan perusahaan dalam keadaan tidak sehat atau krisis. Financial distress yang cukup mengganggu kegiatan operasional perusahaan merupakan suatu kondisi yang harus segera diwaspadai dan diantisipasi. Menurut Platt dalam Luciana (2004), financial distress merupakan tahap penurunan kondisi keuangan yang terjadi sebelum terjadinya kebangkrutan ataupun likuidasi. Apabila hal ini tidak segera diselesaikan akan berdampak besar pada perusahaan-perusahaan seperti hilangnya kepercayaan dari stakeholder, dan bahkan perusahaan akan mengalami kebangkutan.

\section{Profitabilitas}

Profitabilitas adalah kemampuan suatu perusahaan dalam menghasilkan laba selama periode waktu tertentu pada tingkat penjualan, asset dan modal saham tertentu. Profitabilitas merupakan rasio untuk menilai kemampuan suatu perusahaan dalam mencari keuntungan serta memberikan ukuran tingkat efektifitas manajemen suatu perusahaan (Kasmir, 2008). Profitabilitas yang tinggi menunjukan prospek perusahaan yang baik sehingga investor akan merespon positif sinyal tersebut dan nilai perusahaan akan meningkat (Sujoko dan Soebintoro, 2007). Investor menanamkan saham pada sebuah perusahaan dengan tujuan untuk mendapatkan return, yang terdiri dari yield dan capital gain. Semakin tinggi kemampuan memperoleh laba, maka semakin besar return yang diharapkan investor, sehingga menjadikan nilai perusahaan menjadi lebih baik.

\section{Likuiditas}

Likuiditas adalah rasio yang menggambarkan kemampuan perusahaan dalam melunasi kewajiban jangka pendeknya. Menurut Sofyan (2015:301) mengungkapkan bahwa rasio likuiditas menggambarkan kemampuan perusahaan untuk menyelesaikan kewajiban jangka pendeknya. Likuiditas dapat diukur dengan rasio lancar dan rasio quick. Rasio quick yaitu menghitung nilai yang paling likuid, dimana aktiva lancar dikurangi dengan persediaan. Rasio lancar mengukur kemampuan perusahaan memenuhi utang jangka pendeknya dengan aktiva lancar (Mamduh dan Abdul, 2016: 75). Semakin tinggi rasio lancar maka perusahaan dapat menutupi hutang lancarnya dengan aktiva lancar.

\section{Operating Capacity}

Operating capacity atau rasio aktivitas adalah rasio yang digunakan untuk menilai efektif atau tidaknya perusahaan dalam menggunakan aset-aset guna menghasilkan penjualan, sehingga dapat menunjukkan kemampuan aset yang dapat menciptakan penjualan (Atika, 2012). Tingkat operating capacity yang menunjukkan semakin tinggi hasil dari rasio ini maka akan terhindar dari kondisi financial distress perusahaan. Hal tersebut dapat membuat sinyal bagi investor maupun kreditur untuk melakukan investasi dan kreditnya di perusahaan karena perusahaan telah dinilai baik untuk mengatur keuangan perusahaan. Operating capacity yang rendah dapat berpengaruh terhadap kondisi financial distress. 


\section{Sales Growth}

Sales growth atau rasio pertumbuhan penjualan adalah rasio yang digunakan dalam memprediksi suatu pertumbuhan di masa yang akan datang. Rasio ini juga mencerminkan tentang penerapan keberhasilan investasi yang dilakukan perusahaan pada periode yang lalu yang dapat dijadikan sebagai prediksi mengenai pertumbuhan perusahaan dalam periode yang akan datang (Simanjuntak dkk, 2017). Sales growth yang tinggi dapat meningkatkan pendapatan perusahaan dari hasil penjualan yang terjadi selama periode tertentu pada perusahaan tersebut. Hal tersebut menjadi sinyal bagi investor maupun kreditur karena sales growth perusahaan yang tinggi maka akan mempengaruhi aset dan laba perusahaan, sehingga investor dan kreditur tertarik untuk memberikan investasi dan kredit kepada perusahaan. Sales growth menunjukkan angka yang rendah dapat menyebabkan perusahaan mengalami kondisi financial distress karena penjualan yang turun dari periode lalu sehingga dapat mempengaruhi aset, laba, dan hutang perusahaan.

\section{Model Empiris}

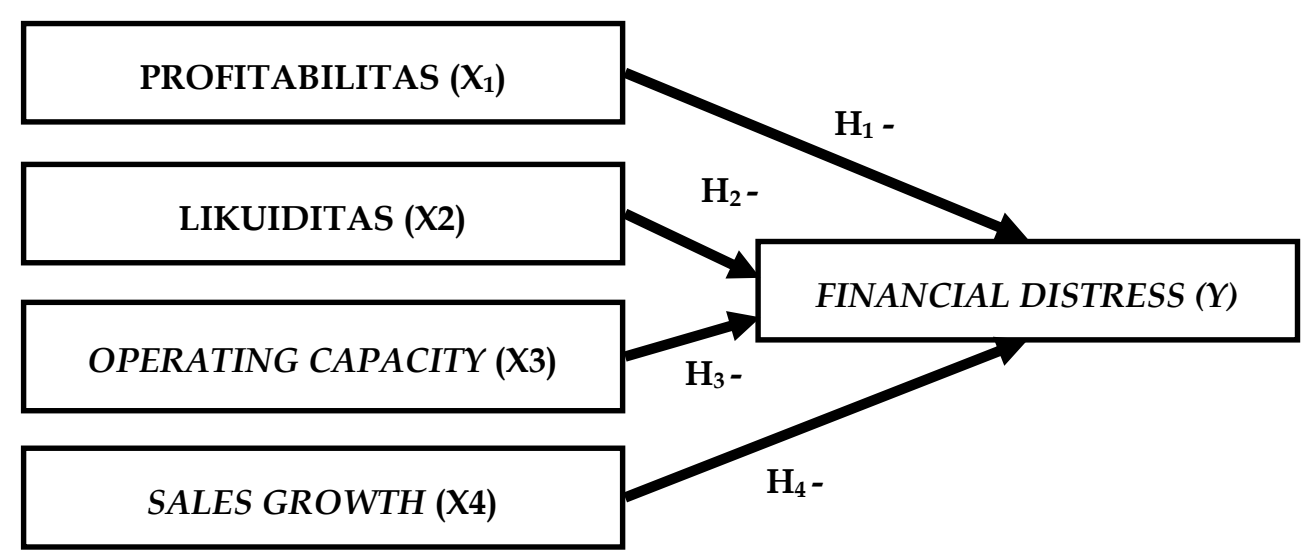

Gambar 1. Konsep Model Empiris

\section{Hipotesis}

Hipotesis dapat diartikan sebagai suatu jawaban yang bersifat sementara terhadap permasalahan penelitian, sampai terbukti melalui data yang terkumpul, mengacu landasan teori yang ada. Berdasarkan uraian tersebut, hipotesis dalam penelitian ini adalah:

$\mathbf{H}_{1}$ : Profitabilitas berpengaruh negatif terhadap kondisi financial distress pada perusahaan manufaktur yang terdaftar di Bursa Efek Indonesia.

$\mathbf{H}_{2}$ : Likuiditas berpengaruh negatif terhadap kondisi financial distress pada perusahaan manufaktur yang terdaftar di Bursa Efek Indonesia.

$\mathbf{H}_{3}$ : Operating Capacity berpengaruh negatif terhadap kondisi financial distress pada perusahaan manufaktur yang terdaftar di Bursa Efek Indonesia.

$\mathbf{H}_{4} \quad$ : Sales Growth berpengaruh negatif terhadap kondisi financial distress pada perusahaan manufaktur yang terdaftar di Bursa Efek Indonesia. 


\section{Metode Penelitian}

\section{Subyek dan Obyek Penelitian}

Subyek yang diambil dalam penelitian ini adalah perusahaan manufaktur yang terdapat dalam Bursa Efek Indonesia (BEI). Sedangkan, obyek penelitian terdiri dari variabel independen (variabel bebas) dan variabel dependen (variabel terikat). Variabel tersebut digunakan dalam menganalisis rasio-rasio keuangan yaitu return on asset (ROA), current ratio (CR), total assets turnover ratio (TATO), dan sales growth (SG) terhadap interest covarage ratio (ICR) pada perusahaan manufaktur yang terdaftar di Bursa Efek Indonesia (BEI).

\section{Populasi dan Sampel Penelitian}

Populasi adalah wilayah generalisasi yang terdiri atas obyek/subyek yang memepunyai kualitas dan karakteristik tertentu yang ditetapkan oleh peneliti untuk dipelajari dan kemudian ditarik kesimpulannya (Sugiyono, 2012: 115). Populasi dalam penelitian ini sebanyak 173 perusahaan manufaktur yang terdaftar di Bursa Efek Indonesia. Sampel adalah bagian dari jumlah dan karakteristik yang dimiliki oleh populasi tersebut (Sugiyono, 2018:137). Adapun kriteria atau pertimbangan pengambilan sampel yang digunakan penulis adalah:

1. Perusahaan manufaktur yang terdaftar di Bursa Efek Indonesia selama periode pengamatan tahun 2015-2018.

2. Perusahaan manufaktur yang mempublikasikan laporan tahunan dan laporan keuangan secara lengkap pada periode 2015-2018.

3. Perusahaan manufaktur yang mengalami kerugian secara 2 tahun berturut-turut atau lebih selama periode 2015-2018.

4. Perusahaan manufaktur yang mengalami laba operasi negatif secara 2 tahun berturut-turut atau lebih selama periode 2015-2018.

Tabel 2. Kriteria Penentuan Sampel

\begin{tabular}{llc}
\hline No & \multicolumn{1}{c}{ Keterangan } & $\begin{array}{c}\text { Perusahaan } \\
\text { Manufaktur }\end{array}$ \\
\hline 1 & $\begin{array}{l}\text { Perusahaan manufaktur yang terdaftar (listing) dalam Bursa Efek } \\
\text { Indonesia (BEI) selama periode 2015-2018 }\end{array}$ & 173 \\
2 & $\begin{array}{l}\text { Perusahaan manufaktur yang tidak menerbitkan laporan tahunan } \\
\text { dan laporan keuangan secara lengkap selama periode 2015-2018 }\end{array}$ & $(43)$ \\
3 & $\begin{array}{l}\text { Perusahaan manufaktur yang mengalami kenaikan laba selama } \\
\text { periode 2015-2018 }\end{array}$ & $(66)$ \\
Perusahaan manufaktur yang mengalami laba fluktuatif pada \\
periode 2015-2018
\end{tabular}

\section{Analisis Statistik Deskriptif}

Menurut Ghozali (2018:19) statistik deskriptif memberikan gambaran deskriptif suatu data yang dilihat dari nilai rata-rata (mean), standard deviasi, varian, maksimum, minimum, sum, range, kurtosis, dan skewness (kemencengan distribusi). Dalam penelitian ini variabel yang digambarkan dengan nilai rata-rata (mean), standard deviasi, varian, maksimum, minimum adalah return on asset (ROA), current ratio (CR), total assets turnover ratio (TATO), sales growth (SG) danInterest Coverage Ratio (ICR). 


\section{Analisis Regresi Logistik (Logistic Regression)}

Menurut Ghozali (2018:325), analisis regresi logistik merupakan alat analisis yang digunakan untuk mengukur seberapa jauh pengaruh variabel independen terhadap variabel dependen, dalam hal ini variabel dependennya dalam bentuk variabel dummy (diantara 0 dan 1 ).

\section{Menilai Kesesuaian Keseluruhan Model (Overall Model Fit)}

Uji kelayakan model logistik adalah uji untuk mengetahui apakah model logistik adalah layak. Menurut Ghozali (2018:332), pengujian ini digunakan untuk mengetahui apakah semua variabel independen didalam regresi logistik secara simultan mempengaruhi variabel dependen sebagaimana uji $\mathrm{F}$ pada regresi linier berganda. Uji statistik yang digunakan berdasarkan pada fungsi Loglikelihood Ratio (LR). Formula Uji LR adalah sebagai berikut:

$$
L R=-2\left(L_{U}-L L_{R}\right)
$$

Uji statistika LR mengikuti distribusi chi square dengan derajat kebebasan (degree of freedom) $\mathrm{n}$ - $\mathrm{k}$ (n jumlah observasi dan k jumlah parameter estimasi). Jika nilai chi square (X2) hitung lebih besar dari nilai kritis atau nilai tabel chi square (X2) maka hipotesis nol dapat ditolak yang berarti modelnya layak. Sedangkan jika sebaliknya maka hipotesis nol gagal ditolak yang berarti modelnya tidak layak. Keputusan dalam menolak atau gagal menolak hipotesis nol dapat menggunakan tingkat probabilitas (sig). Jika probabilitas chi square lebih kecil dari tingkat signifikansi maka menolak hipotesis nol dan sebaliknya gagal menolak hipotesis nol.

\section{Uji Koefisien Determinasi (Nagelkerke's R Square)}

Nagelkerke's R Square merupakan modifikasi dari koefisien Cox and Snell untuk memastikan bahwa nilainya bervariasi dari 0 sampai dengan 1 . Hal ini dilakukan dengan cara membagi nilai Cox and Snell $R^{2}$ dengan nilai maksimumnya. Nilai Nagelkerke's $R^{2}$ dapat diinterpretasikan seperti nilai $R^{2}$ pada multiple regression (Ghozali, 2018:333). Nilai Nagelkerke's $R^{2}$ yang kecil atau mendekati 0 berarti kemampuan variabel-variabel bebas dalam menjelaskan variabel terikat sangat terbatas. Nilai yang mendekati 1 berarti variabel-variabel bebas memberikan hampir semua informasi yang dibutuhkan untuk memprediksi variabel-variabel dependen (Sugiyono, 2016:286).

\section{Uji Kelayakan Model Regresi}

Menurut Ghozali (2018:333), Uji Hosmer dan Lemeshow digunakan untuk menguji hipotesis nol bahwa data empiris cocok atau sesuai dengan model (tidak ada perbedaan antara model dengan data sehingga dapat dikatakan fit). Berikut adalah kriteria dari pengujian Hosmer and Lemeshow Goodness of fit Test:

a. Jika nilai Hosmer and Lemeshow Goodness of fit test statistics sama dengan atau kurang dari 0,05, maka hipotesis nol ditolak yang berarti ada perbedaan signifikan antara model dengan nilai observasinya sehingga Goodness fit model tidak baik karena model tidak dapat memprediksi nilai observasinya.

b. Jika nilai Hosmer and Lemeshow Goodness of fit test statistics lebih besar dari 0,05, maka hipotesis nol tidak dapat ditolak dan berarti model mampu memprediksi nilai observasinya atau dapat dikatakan model dapat diterima karena cocok dengan data observasinya.

\section{Uji Tabel Klasifikasi}

Uji tabel klasifikasi yaitu menghitung nilai estimasi yang benar (correct) dan salah (incorrect) pada kolom merupakan dua nilai prediksi dari variabel dependen dengan kriteria perusahaan 
yang mengalami financial distress (1) dan perusahaan tidak mengalami financial distress (0), sedangkan pada baris menunjukan nilai observasi sesungguhnya dari variabel dependen yang mengalami financial distress (1) dan tidak mengalami financial distress (0). Pada model yang sempurna, maka semua kasus akan berada pada diagonal dengan tingkat ketepatan peramalan $100 \%$. Jika model logistik mempunyai homokedastisitas, maka prosentasi yang benar (correct) akan sama untuk kedua baris (Ghozali, 2018: 334).

\section{Model Regresi Logistik yang Terbentuk}

Model regresi logistik yang terbentuk akan menghasilkan nilai koefisien regresi dan signifikansi. Koefisien regresi dari tiap variabel yang diuji menunjukan bentuk hubungan antar variabel (Ghozali, 2018:325). Menurut Ghozali (2018:334), persamaan model regresi logistik dapat dirumuskan sebagai berikut:

$$
\operatorname{Ln}\left(\frac{p}{1-p}\right)=\beta_{0}+\beta_{1} X_{1}+\beta_{2} X_{2}+\beta_{3} X_{3}+\beta_{4} X_{4}+e
$$

\section{Hasil dan Pembahasan Hasil}

\section{Analisis Deskriptif}

Analisis statistik deskriptif merupakan analisis yang digunakan dalam sebuah penelitian dengan tujuan untuk memberikan gambaran atau mendiskripsikan setiap variabel-variabel yang digunakan pada penelitian ini. Gambaran statistik dari masing-masing variabel pada penelitian ini diperoleh dengan menggunakan SPSS versi 25 yang disajikan pada tabel 3. Berikut ini:

Tabel 3. Descriptive Statistics

\begin{tabular}{lccccc}
\hline & $\mathrm{N}$ & Min & Max & Mean & Std. Dev \\
\hline ROA & 172 & -.5485 & .7160 & -.026404 & .1037029 \\
CR & 172 & .0214 & 7.9248 & 1.469535 & 1.1910781 \\
TAT & 172 & .0008 & 2.4159 & .810686 & .5161670 \\
O & & & & & \\
SG & 172 & -.9998 & 5.9473 & .024725 & .5683929 \\
ICR & 172 & 0 & 1 & .78 & .412 \\
\hline
\end{tabular}

Sumber: Olah data SPSS versi 25, 2019

Berdasarkan tabel 3 menunjukan statistic deskriptif dengan jumlah data yang digunakan dalam penelitian sebanyak 172 sampel. Analisis statistik deskriptif pada tabel 3 dari masing-masing variabel yang terdapat dalam penelitian dapat dijelaskan sebagai berikut ini:

a. Hasil analisis dengan menggunakan statistik deskriptif tehadap return on asset menunjukan nilai minimum sebesar -0,5485 pada PT Intikeramik Alamsari Industri Tbk (IKAI), sedangkan nilai maksimum 0,7160 pada PT Multi Prima Sejahtera Tbk dengan rata-rata sebesar -0,026404 dan standar deviasi sebesar 0,1037029.

b. Hasil analisis dengan menggunakan statistik deskriptif tehadap current ratio menunjukan nilai minimum sebesar 0,0214 pada PT Eterindo Wahanatama Tbk (ETWA), sedangkan 
nilai maksimum sebesar 7,9248 pada PT Multi Prima Sejahtera Tbk (LPIN) dengan ratarata sebesar 1,469535 dan standar deviasi sebesar 1,1910781.

c. Hasil analisis dengan menggunakan statistik deskriptif tehadap total assets turnover ratio menunjukan nilai minimum sebesar 0,0008 pada PT Jakarta Kyoei Steel Works Tbk (JKSW) sedangkan nilai maksimum sebesar 2,4159 pada PT Primarindo Asia Infrastructure Tbk (CEKA) dengan rata-rata sebesar 0,810686dan standar deviasi sebesar 0,5161670 .

d. Hasil analisis dengan menggunakan statistik deskriptif tehadap sales growth menunjukan nilai minimum sebesar -0,9998 pada PT Intikeramik Alamsari Industri Tbk (IKAI), sedangkan nilai maksimum sebesar 5,9473 pada PT Kertas Basuki Rachmat Indonesia Tbk (KBRI) dengan rata-rata sebesar 0,024725 dan standar deviasi sebesar 0,5683929.

e. Hasil analisis dengan menggunakan statistik deskriptif terhadap interest covarage ratio menunjukan nilai minimum sebesar 0 yang berarti perusahaan tidak mengalami kondisi financial distress, sedangkan nilai maksimum sebesar 1 yang berarti perusahaan mengalami kondisi financial distressdengan rata-rata sebesar 0,78 dan standar deviasi sebesar 0,412 .

\section{Analisis Regresi Logistik (Logistic Regression)}

Uji regresi dilakukan karena variabel dependen bersifat dummy (mengalami financial distress dan tidak mengalami financial distress). Tahapan dalam pengujian dengan menggunakan uji regresi logitik dapat dijelaskan sebagaiberikut (Ghozali, 2018):

\section{a. Menilai Kesesuaian Keseluruhan Model (Overall Model Fit)}

Uji ini dilakukan untuk melihat apakah model yang digunakan fit dengan data, yaitu dengan membandingkan nilai -2Log Likelihood pertama (hasil block number 0) dengan nilai -2Log Likehood kedua (hasil block number 1).

Tabel 4. -2 Log likelihood (block number 0)

\begin{tabular}{cccc}
\hline \multicolumn{3}{c}{ Iteration History } \\
\hline Iteration & -2 Log likelihood & $\begin{array}{c}\text { Coefficients } \\
\text { Constant }\end{array}$ \\
\hline Step 0 & 1 & 179.823 & 1.140 \\
& 2 & 179.107 & 1.288 \\
& 3 & 179.106 & 1.294 \\
4 & 179.106 & 1.294 \\
\hline
\end{tabular}

Tabel 5. -2 Log likelihood (block number 1)

\begin{tabular}{|c|c|c|c|c|c|c|c|}
\hline \multicolumn{8}{|c|}{ Iteration History } \\
\hline \multirow{2}{*}{ Iteration } & \multirow{2}{*}{\multicolumn{2}{|c|}{$\begin{array}{l}-2 \quad \text { Lo } \\
\text { likelihood }\end{array}$}} & \multicolumn{5}{|c|}{ Coefficients } \\
\hline & & & Constant & ROA & CR & TATO & SG \\
\hline \multirow[t]{9}{*}{ Step 1} & 1 & 136.321 & 1.960 & -5.755 & -.250 & -.750 & 103 \\
\hline & 2 & 105.325 & 2.622 & -17.172 & -.363 & -1.107 & .223 \\
\hline & 3 & 82.453 & 2.996 & -37.888 & -.426 & -1.246 & .392 \\
\hline & 4 & 71.988 & 3.563 & -61.416 & -.526 & -1.388 & .473 \\
\hline & 5 & 68.743 & 4.089 & -82.588 & -.614 & -1.490 & .347 \\
\hline & 6 & 68.366 & 4.387 & -92.573 & -.660 & -1.564 & 186 \\
\hline & 7 & 68.359 & 4.438 & -94.085 & -.667 & -1.579 & 147 \\
\hline & 8 & 68.359 & 4.439 & -94.115 & -.668 & -1.579 & 146 \\
\hline & 9 & 68.359 & 4.439 & -94.115 & -.668 & -1.579 & .146 \\
\hline
\end{tabular}


Sumber: Output SPSS 25, 2019

Berdasarkan tabel 5 nilai -2 Log likelihood pertama (block number 0) menunjukan nilai sebesar 179,106, sedangkan dalam tabel 6 menunjukan -2 Log likelihood kedua (block number 1) sebesar 68,359 . Hal tersebut menunjukan bahwa terjadi penurunan nilai dari -2 Loglikelihood pertama ke nilai -2 Log likelihood kedua atau dengan kata lain nilai -2 Log likelihood pertama lebih besar dari nilai -2 Log likelihood kedua. Berdasarkan hal tersebut dapat disimpulkan bahwa model yang dihipotesiskan sudah fit dengan data.

\section{Uji Koefisien Determinasi (Nagelkerke's R Square)}

Koefisien determinasi digunakan untuk melihat seberapa besar tingkat variabel independen mempengaruhi variabel dependen. Nagelkerke's $R$ Square merupakan modifikasi dari koefisien Cox and Snell yang merupakan pengujian untuk mengetahui seberapa besar variabel independen mampu menjelaskan dan mempengaruhi variabel dependen.

Tabel 6. Model Summary

\begin{tabular}{lccc}
\hline \multicolumn{3}{c}{ Model Summary } \\
\hline \multirow{2}{*}{ Step } & -2 Log & Cox \& Snell R & Nagelkerke R \\
& likelihood & Square & Square \\
1 & 68.359 a & .475 & .734 \\
\hline \multicolumn{3}{l}{ Sumber: Output SPSS 25, 2019 }
\end{tabular}

Berdasarkan tabel 6 yang telah disajikan, menunjukan bahwa nilai koefisien Nagelkerke $R$ Square sebesar 0,734 yang berarti kemampuan variabel return on asset, current ratio, total asset turnover ratio dan sales growth menjelaskan variabel prediksi financial distress sebesar $73,4 \%$. Sisanya sebesar $26,6 \%$ merupakan faktor lain di luar model penelitian.

\section{Uji Kelayakan Model Regresi}

Uji kelayakan model regresi dengan uji Hosmer and Lemeshow's merupakan uji yang digunakan untuk menilai kelayakan model regresi logistik. Berikut ini adalah hasil pengujian Hosmer and Lemeshow's goodness of fit:

Tabel 7. Uji Hosmer and Lemeshow's

\begin{tabular}{cccc}
\hline \multicolumn{4}{c}{ Hosmer and Lemeshow Test } \\
\hline Step & Chi-square & df & Sig. \\
1 & 4.526 & 8 & .807 \\
Sumber: Output SPSS 25, 2019 & &
\end{tabular}

Tabel 7 menunjukan bahwa nilai Chi Square sebesar 4,526 lebih besar dari pada 0,05 dengan nilai signifikansi sebesar 0,807 lebih besar dari pada 0,05 sehingga model regresi layak digunakan dalam analisis selanjutnya. Hal tersebut disebabkan tidak terdapat perbedaan yang nyata antara klasifikasi yang diprediksi dengan klasifikasi yang diamati. Hasil tersebut menunjukan bahwa model mampu memprediksi nilai observasinya. 


\section{Uji Tabel Klasifikasi}

Ketepatan prediksi klasifikasi digunakan untuk mengetahui nilai etimasi perusahaan yang digolongkan ke dalam kondisi financial distress atau tidak mengalami financial distress.

Tabel 8. Classification Table

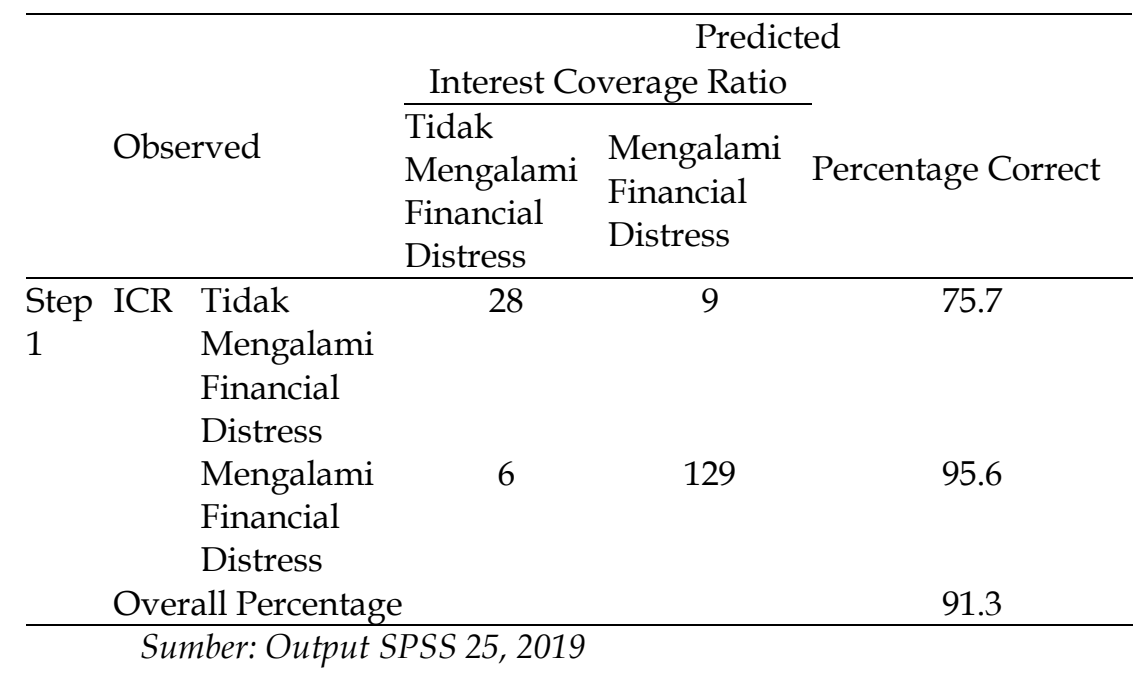

Tabel 8 menunjukan hasil prediksi dan observasi dalam mengklasifikasikan sampel perusahaan yang berada dalam kondisi mengalami financial distress dan tidak mengalami financial distress. Hasil analisis pertama menunjukan bahwa perusahaan yang diprediksikan berada dalam kondisi financial distress sebanyak 37 perusahaan yang merupakan jumlah dari 28+9. Sedangkan hasil observasi menunjukan bahwa sebanyak 28 perusahaan berada pada kondisi tidak mengalami financial distress, namun 9 perusahaan yang semula diprediksikan berada pada kondisi financial distress, setelah dilakukan analisis hasil observasi menunjukan bahwa 9 perusahaan tersebut berada pada kondisi mengalami financial distress dengan ketepatan klasifikasi analisis sebesar 75,7\%.

Hasil analisis kedua menunjukan bahwa perusahaan yang diprediksikan berada dalam kondisi financial distress sebanyak 135 perusahaan yang merupakan penjumlahan dari $6+129$. Sedangkan hasil observasi menunjukan sebanyak 6 perusahaan tetap berada pada kondisi mengalami financial distress, setelah dilakukan analisis observasi menunjukan bahwa 6 perusahaan tidak mengalami kondisi financial distress dengan ketepatan klasifikasi analisis sebesar 95.6\%. Maka ketepatan klasifikasi analisis secara keseluruhan adalah sebesar 91.3\%.

\section{Model Regresi Logistik yang Terbentuk}

Uji regresi logistik dilakukan untuk mengetahui seberapa besar pengaruh hubungan variabel independen terhadap variabel dependen. Besarnya pengaruh variabel independen terhadap variabel dependen secara bersama-sama dapat dihitung melalui suatu persamaan regresi logistik. Hasil uji regresi logistik dapat dilihat pada tabel 9 berikut ini:

Tabel 9. Variables in the Equation

\begin{tabular}{|c|c|c|c|c|c|}
\hline & B & S.E. & Wald & df Sig. & $\operatorname{Exp}(\mathrm{B}$ \\
\hline Step $R O A$ & -94.115 & 19.960 & 22.232 & 1.000 & .000 \\
\hline$C R$ & -.668 & 277 & 5.804 & 1.016 & .513 \\
\hline TATO & -1.579 & 677 & 5.443 & 1.020 & 206 \\
\hline$S G$ & 146 & 1.595 & .008 & $\begin{array}{ll}1.927\end{array}$ & 1.157 \\
\hline Constant & 4.439 & 1.051 & 17.835 & 1.000 & 84.728 \\
\hline
\end{tabular}


Berdasarkan tabel 9 menunjukan nilai beta untuk masing-masing variabel independen, sehingga dapat dikembangkan model persamaan logistik sebagai berikut:

$$
\begin{aligned}
& \operatorname{Ln}\left(\frac{\mathrm{p}}{1-\mathrm{p}}\right)=\beta_{0}+\beta_{1} X_{1}+\beta_{2} X_{2}+\beta_{3} X_{3}+\beta_{4} X_{4}+\mathrm{e} \\
& \operatorname{Ln}\left(\frac{\mathrm{p}}{1-\mathrm{p}}\right)=4,439-94,115 \mathrm{X}_{1}-0,668 \mathrm{X}_{2}-1,579 \mathrm{X}_{3}+0,146 \mathrm{X}_{4}+\mathrm{e}
\end{aligned}
$$

Nilai konstanta dan koefisien regresi logistik pada tabel IV-7 dapat dijelaskan sebagai berikut ini:

1. Konstanta sebesar 4,439 menunjukan bahwa apabila variabel-variabel independen (return on asset, current ratio, total asset turnover ratio dan sales growth) diasumsikan tidak mengalami perubahan (konstan) maka peluang perusahaan mengalami kondisi financial distress sebesar $4,439 \%$.

2. Koefisien variabel Profitabilitas yang diproksikan dengan return on asset (ROA) menunjukan negatif sebesar -94,115 dengan tingkat signifikansi sebesar 0,000, lebih kecil dari $\alpha=0,05$. Hasil ini menunjukan bahwa variabel profitabilitas berpengaruh negatif terhadap kondisi financial distress. Koefisien yang bernilai negatif menunjukan bahwa apabila terjadi penurunan profitabilitas sebesar 1, maka perusahaan akan mengalami kondisi financial distress sebesar $94,115 \%$.

3. Koefisien variabel likuiditas yang diproksikan dengan current ratio(CR) menunjukan negatif sebesar $-0,668$ dengan tingkat signifikansi sebesar 0,016, lebih kecil dari $a=$ 0,05 . Hasil ini menunjukan bahwa variabel likuiditas berpengaruh negatif terhadap kondisi financial distress. Koefisien yang bernilai negatif menunjukan bahwa apabila terjadi penurunan likuiditas sebesar 1, maka perusahaan akan mengalami kondisi financial distress sebesar $0,668 \%$.

4. Koefisien variabel operating capacity yang diproksikan dengan total asset turnover ratio(TATO) menunjukan negatif sebesar $-1,579$ dengan tingkat signifikansi sebesar 0,020 , lebih kecil dari $a=0,05$. Hasil ini menunjukan bahwa variabel operating capacity berpengaruh negatif terhadap kondisi financial distress. Koefisien yang bernilai negatif menunjukan bahwa apabila terjadi penurunan operating capacity sebesar 1, maka perusahaan akan mengalami kondisi financial distress sebesar 1,579\%.

5. Koefisien variabel sales growth yang diukur dengan sales growth (SG) menunjukan sebesar 0,146 dengan tingkat signifikansi sebesar 0,927, lebih besar dari a =0,05. Koefisien yang bernilai positif menunjukan bahwa apabila terjadi kenaikan sales growth sebesar 1, maka perusahaan akan mengalami kondisi financial distress sebesar $0,146 \%$.

\section{Pembahasan}

\section{Pengaruh Profitabilitas Terhadap Kondisi Financial Distress}

Hipotesis pertama yang diajukan dalam penelitian ini adalah profitabilitas yang berpengaruh negatif dan signifikan terhadap financial distress. Hasil analisis menunjukan bahwa koefisien beta variabel profitabilitas sebesar $-94,115$ dengan nilai signifikansi 0,000. Berdasarkan hasil analisis tersebut menunjukan bahwa profitabilitas berpengaruh negatif dan signifikan terhadap financial distress. Hal ini berarti bahwa semakin besar return on asset (ROA) maka semakin kecil kemungkinan perusahaan mengalami financial distress atau dengan kata lain profitabilitas berbanding terbalik terhadap financial distress. Apabila perusahaan mendapatkan profit atau laba yang tinggi maka kemungkinan terjadinya financial distress semakin kecil. Hasil 
tersebut juga menunjukan efisiensi dan efektivitas dari penggunaan aset perusahaan karena rasio profitabilitas mengukur kemampuan perusahaan menghasilkan laba berdasarkan penggunaan aset. Adanya efektivitas penggunaan aset perusahaan maka akan mengurangi biaya yang dikeluarkan oleh perusahaan, dengan begitu perusahaaan akan memperoleh penghematan dan akan memiliki kecukupan dana untuk menjalankan usahanya. Hasil penelitian ini sejalan dengan penelitian yang dilakukan oleh Widarjo dan Setiawan (2009), Hapsari (2012), Andre (2013), Aisyah, Kristanti dan Zultilisna (2017), Ayu, Handayani dan Topowijono (2017), serta Lisiantara dan Febrina (2018) yang menyatakan bahwa profitabilitas berpengaruh negatif secara signifikan terhadap kondisi financial distress.

\section{Pengaruh Likuiditas Terhadap Kondisi Financial Distress}

Hipotesis kedua yang diajukan dalam penelitian ini adalah likuiditas yang berpengaruh negatif dan signifikan terhadap financial distress. Hasil analisis menunjukan bahwa koefisien beta variabel likuiditas sebesar $-0,668$ dengan nilai signifikansi 0,016. Berdasarkan hasil analisis tersebut menunjukan bahwa likuiditas berpengaruh negatif dan signifikan terhadap financial distress. Hal ini berarti bahwa semakin besar adanya ketersediaan atau kecukupan dana untuk memenuhi kewajibannya, maka semakin kecil kemungkinan perusahaan mengalami kondisi financial distress yang mengakibatkan pada kebangkrutan. Hal ini juga dapat dikatakan bahwa rasio likuiditas perusahaan yang semakin besar akan membuat perusahaan semakin dalam keadaan sehat dan semakin baik dalam hal pengelolaannya. Hasil penelitian ini sejalan dengan penelitian yang dilakukan oleh Widhiari dan Merkusiwati (2015), serta Cinantya dan Merkusiwati (2015) yang menyatakan bahwa likuiditas berpengaruh negatif secara signifikan terhadap kondisi financial distress.

\section{Pengaruh Operating Capacity Terhadap Kondisi Financial Distress}

Hipotesis ketiga yang diajukan dalam penelitian ini adalah operating capacity yang berpengaruh negatif dan signifikan terhadap financial distress. Hasil analisis menunjukan bahwa koefisien beta variabel operating capacity sebesar -1,579 dengan nilai signifikansi 0,020. Berdasarkan hasil analisis tersebut menunjukan bahwa operating capacity berpengaruh negatif dan signifikan terhadap financial distress. Hal ini berarti bahwa semakin besar rasio operating capacity maka akan semakin kecil kemungkinan perusahaan mengalami financial distress atau rasio ini menunjukan perbandingan terbalik. Apabila perusahaan dapat menggunakan asetaset guna menghasilkan penjualan secara efektif sehingga dapat menunjukan kemampuan aset yang dimilikinya, maka perusahaan akan semakin terhindar dari kondisi financial distress. Hasil penelitian ini sejalan dengan penelitian yang dilakukan oleh Widhiari dan Merkusiwati (2015) Lisiantara dan Lilik (2018) serta Simanjuntak dkk (2017) yang menghasilkan nilai signifikan negatif, dengan kata lain semakin rendah penjualan perusahaan yang diakibatkan dengan penggunaan aset yang tidak efektif untuk kegiatan operasional, maka perusahaan akan rentan terhadap kondisi financial distress.

\section{Pengaruh Sales Growth Terhadap Kondisi Financial Distress}

Hipotesis keempat yang diajukan dalam penelitian ini adalah sales growth yang berpengaruh negatif dan siginifikan terhadap kondisi financial distress. Hasil analisis menunjukan bahwa koefisien beta variabel sales growth sebesar 0,146 dengan nilai signifikansi 0,927. Berdasarkan hasil analisis tersebut menunjukan bahwa sales growth tidak memiliki pengaruh terhadap kondisi financial distress. Hasil penelitian ini menolak hipotesis empat yang menyatakan sales growth berpengaruh negatif terhadap kondisi financial distress pada perusahaan manufaktur yang terdaftar di Bursa Efek Indonesia periode 2015 sampai dengan 2018. Hal ini berarti bahwa pertumbuhan penjualan yang dialami oleh perusahaan dari tahun ke tahun tidak dapat mempengaruhi kondisi financial distress secara langsung pada perusahaan karena terdapat 
faktor lain yang lebih kuat dalam mempengaruhi kondisi financial distress perusahaan secara langsung. Hasil penelitian ini sejalan dengan penelitian yang dilakukan oleh Widarjo dan Setiawan (2009), Liana dan Sutrisno (2014), Rani (2017), serta Lisiantara dan Febrina (2018) yang menyatakan bahwa sales growth tidak dapat mempengaruhi terjadi kondisi financial distress.

\section{Penutup dan Implikasi}

\section{Simpulan}

Berdasarkan hasil analisis yang telah dibahas pada pembahasan bab sebelumnya mengenai kondisi financial distress pada perusahaan manufaktur yang terdaftar di Bursa Efek Indonesia periode 2015-2018, maka dapat diambil beberapa kesimpulan sebagai berikut:

1. Hasil penelitian menunjukan bahwa profitabilitas berpengaruh terhadap kondisi financial distress pada perusahaan manufaktur yang tercatat di Bursa Efek Indonesia periode 20152018, sehingga hipotesis pertama (H1) diterima, artinya setiap peningkatan atau penurunan profitabilitas mempengaruhi kondisi financial distress pada perusahaan manufaktur yang tercatat di Bursa Efek Indonesia periode 2015-2018. Apabila terjadi peningkatan profitabilitas, maka resiko perusahaan mengalami kondisi financial distress akan semakin kecil. Sebaliknya, apabila terjadi penurunan profitabilitas maka resiko perusahaan mengalami kondisi financial distress akan semakin besar.

2. Hasil penelitian menunjukan bahwa likuiditas berpengaruh terhadap kondisi financial distress pada perusahaan manufaktur yang tercatat di Bursa Efek Indonesia periode 20152018, sehingga hipotesis kedua $\left(\mathrm{H}_{2}\right)$ diterima, diartikan setiap peningkatan atau penurunan likuiditas dapat mempengaruhi kondisi financial distress pada perusahaan manufaktur yang tercatat dalam Bursa Efek Indonesiaperiode 2015-2018. Adanya ketersediaan atau kecukupan dana untuk memenuhi kewajibannya, maka semakin kecil kemungkinan perusahaan mengalami kondisi financial distress yang mengakibatkan pada kebangkrutan. Hal ini juga dapat dikatakan bahwa likuiditas perusahaan yang semakin besar akan membuat perusahaan semakin dalam keadaan sehat dan semakin baik dalam hal pengelolaannya.

3. Hasil penelitian menunjukan bahwa operting capacity berpengaruh terhadap kondisi financial distress pada perusahaan manufaktur yang tercatat di Bursa Efek Indonesia periode 20152018, sehingga hipotesis ketiga $\left(\mathrm{H}_{3}\right)$ diterima, artinya setiap peningkatan atau penurunan operating capacity mempengaruhi kondisi financial distress pada perusahaan manufaktur yang tercatat di Bursa Efek Indonesia periode 2015-2018. Semakin rendah penjualan perusahaan yang diakibatkandengan penggunaan aset yang tidak efektif untuk kegiatan operasional, maka perusahaan akan rentan terhadap kondisi financial distress.

4. Hasil penelitian menunjukan bahwa sales growth tidak berpengaruh terhadap kondisi financial distress pada perusahaan manufaktur yang tercatat di Bursa Efek Indonesia periode 2015-2018, sehingga hipotesis keempat $\left(\mathrm{H}_{4}\right)$ ditolak, artinya setiap peningkatan atau penurunan sales growth tidak mempengaruhi kondisi financial distress pada perusahaan manufaktur yang tercatat di Bursa Efek Indonesia periode 2015-2018. Adanya penjualan yang rendah atau tinggi tidak mampu mempengaruhi perusahaan terhadap kondisi financial distress. 


\section{Keterbatasan}

Berdasarkan pembahasan serta kesimpulan yang diperoleh dari penelitian, ternyata masih banyak kekurangan mengenai isi dan hasil didalamnya. Oleh karena itu, penelitian ini memiliki keterbatasan yaitu sebagai berikut:

1. Penelitian ini hanya menggunakan beberapa rasio keuangan yaitu profitabilitas, likuiditas, operating capacity dan sales growth untuk mengetahui seberapa besar pengaruh terhadap kondisi kesulitan keuangan atau financial distress pada perusahaan manufaktur yang terdaftar di Bursa Efek Indonesia periode 2015-2018.

2. Sampel pada penelitian ini merupakan perusahaan manufaktur yang terdaftar di Bursa Efek Indonesia periode 2015-2018 dengan jumlah sempel yang relatif sedikit untuk analisis regresi logistik.

3. Salah satu variabel pada penelitian ini menggunakan sales growth, yang hasilnya tidak dapat mempengaruhi terjadinya kondisi financial distress secara langsung, karena terdapat faktor lain diluar penelitian yang mampu memprediksi kondisi financial distress.

4. Penelitian ini menggunakan variabel financial distress dengan pengukuran interest coverage ratio (ICR) yang menggunakan perhitungan earning before interest taxs (EBIT) dibagi interest expence atau biaya bunga.

5. Penelitian ini hanya menggunakan beberapa rasiokeuangan yang hasilnya hanyalah mengukur seberapa besar pengaruh rasio keuangan tersebut dalam memprediksi kondisi terjadinya financial distress.

\section{Implikasi Praktis}

Penelitian ini diharapkan dapat memberikan berbagai manfaat terhadap pihak-pihak yang terkait, antara lain:

1. Bagi penulis sendiri, penelitian ini diharapkan dapat membuka wawasan dan ilmu pengetahuan mengenai perusahaan-perusahaan yang mengalami kondisi kesulitan keuangan atau sering disebut financial distress dengan menggunakan rasio keuangan sebagai tolak ukur kondisi tersebut.

2. Bagi perusahaan yang telah terindikasi mengalami kondisi kesulitan keuangan atau financial distress seharusnya segera dapat mengantisipasi dan berbenah sehingga dapat menghindari terjadi kebangkrutan. Kesulitan keuangan atau financial distress yang tidak diperbaiki akan menimbulkan terjadinya kebangkrutan sehingga membuat perusahaan tidak dapat melakukan operasi perusahaannya.

3. Bagi investor yang akan menginvestasikan dananya, untuk lebih teliti dan berhati-hati dalam mengambil keputusan investasi terhadap perusahaan yang telah mengalami kondisi kesulitan keuangan atau financial distress. Tingkat kesulitan keuangan dapat dilihat dari beberapa rasio keuangan seperti rasio profitabilitas yang menggambarkan laba perusahaan, likuiditas perusahaan yang menggambarkan hutang dan rasio aktivitas perusahaan yang menggambarkan operasi perusahaan.

4. Bagi kalangan akademis, penelitian ini diharapkan dapat digunakan sebagai literatur untuk memperkaya pengetahuan serta mengembangkan teori mengenai profitabilitas yang merupakan laba perusahaan. Hal ini membuktikan bahwa, apabila laba perusahaan semakin tinggi maka kondisi kesulitan keuangan atau financial distress semakin rendah dan dapat ditekan. Selanjutnya likuiditas perusahaan yang merupakan hutang perusahaaan yang dapat dikelola. Hal ini membuktikan bahwa apabila kecukupan dana untuk membayar hutang maka kondisi kesulitan keuangan atau financial distress semakin rendah 
dan dapat ditekan. Serta operating capacity yang berarti bahwa semakin rendah penjualan perusahaan yang diakibatkan dengan penggunaan aset yang tidak efektif untuk kegiatan operasional, maka perusahaan akan rentan terhadap kondisi financial distress.

\section{Implikasi Teoritis}

Berdasarkan hasil pengujian mengenai profitabilitas, likuiditas, operating capacity serta sales growth terhadap kondisi financial distress terdapat beberapa temuan dalam penelitian ini. Temuan tersebut memberikan dukungan secara empiris terhadap teori-teori yang telah disampaikan dalam bab II, antara lain:

1. Hasil penelitian ini membuktikan bahwa profitabilitas berpengaruh negatif terhadap kondisi financial distress pada perusahaan manufaktur. Hal ini berarti dengan adanya peningkatan profitabilitas, maka resiko perusahaan mengalami kondisi financial distress akan semakin kecil. Sebaliknya, apabila terjadi penurunan profitabilitas maka resiko perusahaan mengalami kondisi financial distress akan semakin besar. Hasil penelitian ini sejalan dengan penelitian yang dilakukan oleh Widarjo dan Setiawan (2009), Hapsari (2012), Andre (2013), Aisyah, Kristanti dan Zultilisna (2017), Ayu, Handayani dan Topowijono (2017), serta Lisiantara dan Febrina (2018) yang menyatakan bahwa profitabilitas berpengaruh negatif secara signifikan terhadap kondisi financial distress.

2. Hasil penelitian ini membuktikan bahwa likuiditas berpengaruh negatif terhadap financial distress. Hal ini berarti bahwa semakin besar adanya ketersediaan atau kecukupan dana untuk memenuhi kewajibannya, maka semakin kecil kemungkinan perusahaan mengalami kondisi financial distress yang mengakibatkan pada kebangkrutan. Hal ini juga dapat dikatakan bahwa rasio likuiditas perusahaan yang semakin besar akan membuat perusahaan semakin dalam keadaan sehat dan semakin baik dalam hal pengelolaannya. Hasil penelitian ini sejalan dengan penelitian yang dilakukan oleh Widhiari dan Merkusiwati (2015), serta Cinantya dan Merkusiwati (2015) yang menyatakan bahwa likuiditas berpengaruh negatif secara signifikan terhadap kondisi financial distress.

3. Hasil penelitian ini membuktikan bahwa operating capacity berpengaruh negatif terhadap financial distress. Hal ini berarti bahwa semakin efektifnya penggunan aset-aset untuk menghasilkan penjualan akan semakin dapat menghindarkan perusahaan pada kondisi financial distress. Hasil penelitian ini sejalan dengan penelitian yang dilakukan oleh Widhiari dan Merkusiwati (2015) Lisiantara dan Lilik (2018) serta Simanjuntak dkk (2017) yang menghasilkan nilai signifikan negatif, dengan kata lain semakin rendah penjualan perusahaan yang diakibatkan dengan penggunaan aset yang tidak efektif untuk kegiatan operasional, maka perusahaan akan rentan terhadap kondisi financial distress.

4. Hasil penelitian ini membuktikan bahwa sales growth tidak memiliki pengaruh terhadap kondisi financial distress. Hal ini membuktikan bahwa tingkat naik turunnya penjualan pada perusahaan manufaktur tidak dapat mempengaruhi terjadinya kondisi financial distress secara langsung. Hasil penelitian ini sejalan dengan penelitian yang dilakukan oleh Widarjo dan Setiawan (2009), Liana dan Sutrisno (2014), Rani (2017), serta Lisiantara dan Febrina (2018) yang menyatakan bahwa sales growth tidak dapat mempengaruhi terjadi kondisi financial distress. 


\section{Referensi}

Aisyah, N., Kristanti, F., \& Zutilisna, D. (2017). Pengaruh Rasio Likuiditas, Rasio Aktivitas, Rasio Profitabilitas, Dan Rasio Leverage Terhadap Financial Distress (studi Kasus Pada Perusahaan Tekstil Dan Garmen Yang Terdaftar Di Bursa Efek Indonesia Tahun 20112015). eProceedings of Management, 4(1).

Almilia, L. S. (2004). Analisis Faktor-Faktor yang Mempengaruhi Kondisi Financial istress Suatu Perusahaan yang Terdaftar di Bursa Efek Jakarta. The Indonesian Journal of Accounting Research, 7(1).

Almilia, L. S., \& Kristijadi, K. (2003). Analisis rasio keuangan untuk memprediksi kondisi financial distress perusahaan manufaktur yang terdaftar di bursa efek Jakarta. Jurnal Akuntansi dan Auditing Indonesia, 7(2).

Andre, O., \& Taqwa, S. (2014). Pengaruh Profitabilitas, Likuiditas, dan Leverage Dalam Memprediksi Financial Distress (Studi Empiris Pada Perusahaan Aneka Industri yang Terdaftar di BEI Tahun 2006-2010). Wahana Riset Akuntansi, 2(1).

Ardiyanto, F. D., \& Prasetiono, P. (2011). Prediksi Rasio Keuangan Terhadap Kondisi Financial Distress Perusahaan Manufaktur yang Terdaftar di BEI. Jurnal Dinamika Ekonomi $\mathcal{E}$ Bisnis, 8(1).

Ayu, A. S., Handayani, S. R., \& Topowijono, T. (2017). Pengaruh Likuditas, Leverage, Profitabilitas, dan Ukuran Perusahaan Terhadap Financial Distress Studi pada Perusahaan Manufaktur Sektor Industri Dasar dan Kimia yang Terdaftar di Bursa Efek Indonesia tahun 2012-2015. Jurnal Administrasi Bisnis, 43(1), 138-147.

Cinantya, I. G. A. A. P., \& Merkusiwati, N. K. L. A. (2015). Pengaruh corporate governance, financial indicators, dan ukuran perusahaan pada financial distress. E-Jurnal Akuntansi Universitas Udayana, 10(3), 897-915.

Dewi, R. J. T., Khairunnisa, K., \& Mahardika, D. P. (2017). Analisis Pengaruh Likuiditas, Leverage, Dan Operating Capacity Terhadap Financial Distress Perusahaan Pertambangan (studi Pada Perusahaan Pertambangan Yang Terdaftar Di Bursa Efek Indonesia 2013-2015). eProceedings of Management, 4(3).

Dwijayanti, S., \& Febrina, P. (2010). Penyebab, dampak, dan pbediksi dari financial distress serta solusi untuk mengatasi financial distress. Jurnal Akuntansi Kontemporer, 2(2), 191205.

Eliu, V. (2014). Pengaruh Financial Leverage dan Firm Growth Terhadap Financial Distress. Finesta, 2(2), 6-11.

Fahmi, I. (2012). Analisis Laporan Keuangan. Bandung: CV Alfabeta

Ghozali, I. (2006). Aplikasi Analisis Multivariate Dengan Program SPSS 25. Edisi I. Semarang: Badan Penerbit Universitas Diponegoro.

Ghozali, I. 2009. Ekonometrika Teori, Konsep dan Aplikasi dengan SPSS 17. Semarang: Badan Penerbit Universitas Diponegoro.

Ghozali, I. 2018. Aplikasi Analisis Multivariate Dengan Program IBM SPSS 25. Edisi 9. Semarang: Badan Penerbit Universitas Diponegoro.

Hanafi, M., \& Halim, A. (2003). Analisis Laporan Keuangan. Edisi Revisi. Yogyakarta: UPP AMP YKPN. 
Hanafi, M., \& Halim, A. (2007). Analisis Laporan Keuangan. Edisi 3. Yogyakarta: Sekolah Tinggi Ilmu Manajemen YPKN.

Hapsari, E. I. (2012). Kekuatan Rasio Keuangan dalam Memprediksi Kondisi Financial Distress Perusahaan Manufaktur di BEI. JDM (Jurnal Dinamika Manajemen), 3(2).

Hidayat, R. N. (2010). Analisis Financial Distress Perusahaan Melalui Pendekatan Logit pada Perusahaan Manufaktur Yang Terdaftar di Bursa Efek Indonesia Periode 20022006. Skripsi. Universitas Negeri Yogyakarta.

Hofer, C.W. 1980. Turnaround Strategies. Journal of Business Strategy. Vol 1, No 1. Hal 19-13.

Iramani, R. (2007). Analisis Struktur Kepemilikan dan Rasio Relatif Industri Sebagai Prediktor dalam Model Kesulitan Keuangan. Jurnal Bisnis dan Manjemen, 1(1), 1-13.

Kasmir. (2015). Analisis Laporan Keuangan. Jakarta: PT Raja Grafindo Persada.

Liana, D \& Sutrisno, S. (2014). Analisis Rasio Keuangan Untuk Mempresiksi Kondisi Financial Distress Perusahaan Manufaktur. Jurnal Studi Manajemen dan Bisnis, 1(2), 52-62.

Lisiantara, G. A., \& Febrina, L. (2018). Likuiditas, Leverage, Operating Capacity, Profitabilitas, Sales Growth sebagai Preditor Financial Distress (Studi Empiris Pada Perusahaan Manufaktur Yang Terdaftar di Bursa Efek Indonesia tahun 2013-2016).

Putri, N. W. K. A., \& Merkusiwati, N. K. L. A. (2014). Pengaruh mekanisme corporate governance, likuiditas, leverage, dan ukuran perusahaan pada financial distress. EJurnal Akuntansi Universitas Udayana, 7(1), 93-106.

Rani, D. R. (2017). Pengaruh Likuiditas, Leverage, Profitabilitas, Agency Cost dan Sales Growth Terhadap Kemungkinan Terjadinya Financial Distress (Studi Empiris Pada Perusahaan Manufaktur yang Terdaftar Di Bursa Efek Indonesia Tahun 2012-2015). Jom Fekon, 4(1), 3661-3675.

Santoso, S. (2018). Menguasai Statistik dengan SPSS 25. Jakarta: PT Alex Media Komputindo.

Sarwono, J. (2018). Statistik Untuk Riset Skripsi. Yogyakarta: CV Andi Offset.

Scott, W. R. (2014). Financial Accounting Theory. Toronto: Pearson Prentice Hall.

Simanjuntak, C. E. B., Krist, F. T., \& Aminah, W. (2017). Pengaruh Rasio Keuangan Terhadap Financial Distress. eProceedings of Management, 4(2).

Sugiyono. (2012). Metode Penelitian Bisnis Pendekatan Kuantitatif, Kualitatif, Kombinasi dan RED. Bandung: Alfabeta.

Sugiyono. 2017. Metode Penelitian Bisnis Pendekatan Kuantitatif, Kualitatif, Kombinasi dan RED. Bandung: Alfabeta.

Sugiyono. 2018. Metode Penelitian Bisnis Pendekatan Kuantitatif, Kualitatif, Kombinasi dan RED. Bandung: Alfabeta.

Sujoko, S., \& Soebiantoro, U. (2007). Pengaruh struktur kepemilikan saham, leverage, faktor intern dan faktor ekstern terhadap nilai perusahaan (studi empiris pada perusahaan manufaktur dan non manufaktur di Bursa Efek Jakarta). Jurnal Manajemen dan Kewirausahaan, 9(1), 41-48.

Toto, P. (2008). 7 Analisis Rasio Keuangan. Jakarta: PPM. 
Whitaker, R. B. (1999). The early stages of financial distress. Journal of Economics and Finance, 23(2), 123-132.

Widarjo, W., \& Setiawan, D. (2009). Pengaruh rasio keuangan terhadap kondisi financial distress perusahaan otomotif. Jurnal bisnis dan akuntansi, 11(2), 107-119.

Widarjono, A. (2018). Analisis Regresi Dengan SPSS. Edisi I. Yogyakarta: UPP STIM YKPN.

Widhiari, N. L. M. A., \& Merkusiwati, N. K. L. A. (2015). Pengaruh rasio likuiditas, leverage, operating capacity, dan sales growth terhadap financial distress. E-Jurnal Akuntansi Universitas Udayana, 11(2), 456-469. 